\title{
Erratum to: Resin glycosides from Convolvulaceae plants
}

\author{
Masateru Ono ${ }^{1}$
}

Published online: 12 September 2017

(C) The Japanese Society of Pharmacognosy and Springer Japan KK 2017

\section{Erratum to: J Nat Med DOI 10.1007/s11418-017-1114-5}

The article Resin glycosides from Convolvulaceae plants, written by Masateru Ono, was originally published electronically on the publisher's internet portal (currently SpringerLink) on 26 July 2017 without open access.

With the author(s)' decision to opt for Open Choice the copyright of the article changed on 26 July 2017 to (c) The
Author(s) 2017 and the article is forthwith distributed under the terms of the Creative Commons Attribution 4.0 International License (http://creativecommons.org/licen ses/by/4.0/), which permits use, duplication, adaptation, distribution and reproduction in any medium or format, as long as you give appropriate credit to the original author(s) and the source, provide a link to the Creative Commons license and indicate if changes were made.

The online version of the original article can be found under doi: $10.1007 / \mathrm{s} 11418-017-1114-5$.

\footnotetext{
Masateru Ono

mono@agri.u-tokai.ac.jp

1 School of Agriculture, Tokai University, 9-1-1 Toroku, Higashi-ku, Kumamoto 862-8652, Japan
} 